\title{
4-butoxybenzylidene-4'-butylaniline (BBBA) Sıvı Kristalinin Geniş Sıcaklık Aralığında İncelenmesi: Optik, Dielektrik, Kalorimetrik ve Kızıötesi Spektroskopik Analiz
}

\author{
Atilla Eren MAMUK ${ }^{*}$, Nejmettin AVCI \\ Muğla Sitkı Koçman Üniversitesi, Fen Fakültesi, Fizik Bölümü, 48000, Muğla, Türkiye \\ (ORCID: 0000-0002-1524-3342) (ORCID: 0000-0001-9189-1176)
}

\begin{abstract}
$\ddot{\mathbf{O z}}$
$\mathrm{Bu}$ çalışmada nematik ve farklı smektik mezofazlar sergileyen alkyloxy benzylidene alkylanilines sınıfına ait Schiff bazlı 4-butoxybenzylidene-4'-butylaniline (BBBA) sıvı kristalinin bazı fiziksel özellikleri incelenmiştir. Literatürde BBBA sıvı kristali üzerine çalışmalar oldukça az ve yetersizdir. Bu amaçla, morfolojik özelliklerinin belirlenmesi için optik tekstürleri mezofaz bölgelerinde ve faz geçiş bölgelerinde incelenmiştir. Optik tekstür analizlerinden BBBA'nın sergilediği mezofazlarda ortaya çıkan desenler belirlenmiştir. Ayrıca, dielektrik ölçümler 1sıtma ve soğutma durumları için ayarı ayrı incelenerek her iki durum için dielektrik anizotropinin her bir mezofaz bölgesinde nasıl davrandığı araştırılmıştır. Yapılan araştırmalarda ısıtma ve soğutma durumlarında faz geçişler için termal histerezisin varlığı ortaya konulmuştur. Sıvı kristalik özellik sergilediği sıcaklık aralığında birçok mezofazın ortaya çıktığı BBBA’nın kızılötesi spektroskopik ölçümleri gerçekleştirilerek molekülün temel titreşim modları analiz edilmiştir. Ayrıca, BBBA’nın diferansiyel tarama kalorimetrisi yöntemi ile kalorimetrik ölçümleri hem ısıtma hem de soğutma durumları için yapılarak faz geçiş sıcaklıkları ve faz aralığı belirlenmiş̧tir. Elde edilen kalorimetrik sonuçlar dielektrik ölçümlerden elde edilenler ile kıyaslanmıştır. Birçok mezofazı sergilemesi ve hakkında literatürde yeterince çalışmanın olmaması dolayısıyla BBBA sıvı kristali bilimsel araştırmalarda üzerine daha fazla araştırma yapılması gereken bir sıvı kristaldir.
\end{abstract}

Anahtar kelimeler: Sıvı kristaller, dielektrik, optik, DSC, FTIR, tekstür

\section{Examination of 4-butoxybenzylidene-4'-butylaniline (BBBA) Liquid Crystal in Wide Temperature Range: Optical, Dielectric, Calorimetric and Infrared Spectroscopic Analysis}

\begin{abstract}
In this study, some physical properties of Schiff-based 4-butoxybenzylidene 4'-butylaniline (BBBA) liquid crystal belonging to alkyloxy benzylidene alkylanilines class with nematic and different smectic mesophase were investigated. Studies on BBBA liquid crystal are very few and insufficient in the literature. Due to this case, optical textures were examined in mesophase regions and phase transition regions to determine morphological properties. Patterns emerging in the mesophase exhibited by BBBA were determined from the optical texture analysis. In addition, the dielectric measurements were examined separately for heating and cooling conditions, and how the dielectric anisotropy behaves in each mesophase region for both cases. In the researches, the existence of thermal hysteresis for phase transitions in heating and cooling conditions has been revealed. The infrared spectroscopic measurements of the BBBA, in which many mesophases emerge in the temperature range in which it exhibits liquid crystalline properties, were performed and the fundamental vibration modes of the molecule were analyzed. In addition, the calorimetric measurements of the BBBA with the differential scanning calorimetry method were made for both heating and cooling conditions, and phase transition temperatures and phase range were determined. The calorimetric results obtained were compared with those obtained from dielectric measurements. The BBBA liquid crystal is a liquid crystal that needs more research in scientific research due to the fact that it exhibits many mesophase and there are not enough studies in the literature.
\end{abstract}

Keywords: Liquid crystals, dielectric, optic, DSC, FTIR, texture

\footnotetext{
*Sorumlu yazar: aemamuk@mu.edu.tr

Geliş Tarihi: 27.12.2020, Kabul Tarihi: 05.05.2021
} 


\section{Giriş}

Sıvı kristaller anizotropik karakterleriyle bilinen ve bu karakteriyle çeşitli fiziksel özelliklere sahip önemli bir malzeme sınıfını temsil ederler. Halihazırda sıvı kristal ekranlar ve polimerle dağınık sıvı kristaller gibi pek çok görüntüleme ve görselleştirme teknolojisi alanında uygulanmaktadırlar [1-3]. Bazı sıvı kristaller, moleküler elektronik alanında çeşitli uygulamalar öneren yararlı yarı iletken özelliklere sahiptir. Bu moleküller, fotovoltaik cihazlarda aktif katmanlar olarak kullanımları için gerekli özellikleri sağlar [4]. Sıvı kristaller ayrıca yeni holografik tekniklere göre veri depolama alanındaki ilginç malzemeleri temsil etmektelerdir [5].

Moleküllerinin düzen derecesine bağlı olarak sıvı kristaller farklı alt fazlar sergileyebilirler. Bu alt fazlar mezofaz olarak adlandırılmaktadır. Sıvı kristal moleküllerinin dinamikleri bir mezofazdan diğerine geçişten etkilenmektedir [1]. En basit sıvı kristalik faz olarak değerlendirilen nematik (N) mezofazda zayıf yönelimsel düzen mevcuttur. Söz konusu mezofazda moleküller ortalama olarak bir $\boldsymbol{n}$ yön vektörü boyunca dizilirler. Sıvı kristallerde farklı moleküler düzen ve yönelimine sahip birçok smektik mezofaz bulunmaktadır. Smektik mezofazlarda moleküller ortalama olarak ağırlık merkezleri boyunca dizilerek katmanlı yapı oluşturmaktadırlar. Smektik yapıda eğer yön vektörü molekül tabakalarına dik şekilde yönelmiş ise bu tür mezofaz smektik A (SmA) olarak adlandırılmaktadır. Eğer yön vektörü söz konusu katmanlara $90^{\circ}$ 'den farklı bir açı ile yönelmiş ise bu tür mezofaz ise smektik C (SmC) mezofazı olarak adlandırılmaktadır. 2-boyutlu sıvı kristaller olarak da değerlendirilen SmA ve SmC sıvı kristallerinde katmanlar içindeki moleküler konumlar arasında, tipik olarak birkaç moleküle karşılık gelen bir mesafe boyunca yalnızca kısa menzilli korelasyon vardır [6]. Smektik B (SmB) ise bileşen molekülleri hegzagonal bir düzeni benimseyen fakat hegzagonal örgülerin sadece $\sim 150-600 \AA ̊$ üzerinde tekrar eden konumsal düzene sahip olduğu SmA'nın daha düzenli halidir. Tüm bu smektik fazlarının dışında farklı kristalik düzenlere kısmen sahip smektik mezofazlar da bilinmektedir [7]. Bu gibi termodinamik olarak kararlı mezofazlar hareketli doğaları yani akışla karakterize edilmektedirler. Bunun yanı sıra optiksel ve diğer anizotropilerini göstermeleri ile tanımlanmaktadırlar. Mezofazlarda normal katı kristallere göre moleküller arası etkileşim çok küçüktür. Ayrıca, smektik-smektik, smektiknematik veya nematik-izotropik sıvı fazları arası geçişlerde tanımlanan 1sı, katı kristal-mezofaz geçişine kıyasla çok küçüktür. Mezofazlar için yapılan kalorimetrik çalışmalar mezofaz ve izotropik fazlar arası faz geçişin yakınlarındaki geçiş öncesi etkileri göstermesi açısından oldukça kıymetlidir [8].

4-butoxybenzylidene-4'-butylaniline (BBBA) siv1 kristali alkyloxy benzylidene alkylanilines $(\mathrm{nO} \cdot \mathrm{m})$ sınıfına ait Schiff bazlı smektojenik bir sıvı kristaldir. Uç zincirlerdeki karbon atom sayısına karşıllık gelen değerler bu molekül için $n=4$ ve $m=4$ 'tür. Bu sınıftaki moleküller uzun zincirli alifatik bileşiklerdir. Bu tür sıvı kristaller birçok mezofaz içermeleri bakımından faz geçiş mekanizmalarının anlaşılması hususunda bilimsel çalışmalarda sıklıkla kullanılan malzemelerdir. nO $\cdot \mathrm{m}$ sınıfındaki homolog serileri daha geniş kapsamlı uygulamalarının yanı sıra, sistematik olarak çeşitlendirmenin kolay olması nedeniyle büyük ilgi görmektedir. $m$ ve $n$ 'yi değiştirerek bu sistemlerin moleküler yapıları ve bu tür varyasyonların bu sıvı kristallerin fiziksel özellikleri üzerindeki etkisi yaygın şekilde araştırılmaktadır [9-17].

BBBA sıvı kristalinin fiziksel özellikleri üzerine yapılan çalışmalar görece azdır. Bu çalışmada BBBA sıvı kristalinin tekstürleri incelenerek optik özellikleri ve faz geçiş sıcaklıkları araştırılmıştır. Geniş sıcaklık aralığında kalorimetrik ölçüm yapılarak faz geçiş sıcaklıklarının ısıtma ve soğutma süreçlerinde davranışı incelenmiştir. Malzemenin kızılötesi spektroskopisi yapılarak kimyasal süreçleri ve yapıları hakkında bilgi edinilmiştir. Moleküllerin özelliklerini ve mezofazların bütün halde tepkisini belirtmesi sebebiyle sıvı kristallerin dielektrik davranışının incelenmesi önemlidir. Sıvı kristallerde makroskobik kutuplanma ile iç elektrik alan kaynaklı moleküler tepki arasında bir bağlantı vardır. Mezofazların dielektrik özelliklerinin moleküler seviyede incelenmesi için anizotropik ortamda iç elektrik alan koşullarının belirlenmesi oldukça önemlidir [18-21]. Bu sebeple BBBA'nın mezofaz bölgesinde dielektrik geçirgenliğinin frekans ve sıcaklığa bağımlılığı incelenmiştir. 


\section{Materyal ve Metot}

Makalede araştırılan sıv1 kristal 4-butoxybenzylidene-4'-butylaniline (BBBA) olup, BDH Ltd. firmasından ticari olarak elde edilmiştir. Bu sıvı kristal (nO - m) sınıfına ait Schiff bazlı ve uç molekül zincirlerinde karbon atom sayıları $\mathrm{n}=4$ ve $\mathrm{m}=4$ olan bir termotropik sıvı kristaldir. BBBA'ya ait molekül formülü Şekil 1'de verilmektedir Sıvı kristalin faz geçiş sıcaklıkları ve optik tekstürleri Olympus BX51P polarizasyon mikroskobu (POM) kullanılarak elde edilmiştir. Dielektrik ölçümleri gerçekleştirmek için Solatron SI1260 marka empedans analizörü kullanılmıştır. BBBA sıvı kristalinin faz geçiş karakteristiklerinin sıcaklığın değişimine bağlı belirlenebilmesi için Diferansiyel Taramalı Kalorimetri (Differential Scanning Calorimetry-DSC) ölçümlerinin yapılabilmesi için Perkin Elmer DSC 8000 model kalorimetri ölçüm cihazı kullanılmıştır. Ölçümü yapabilmek için ilk olarak, BBBA sıvı kristali bir alüminyum kaba konulmuştur. Ölçümlerde referans ağıllık olması için boş kabın ağırlığı ölçülmüş ve ölçüm değeri $0,002 \mathrm{mg}$ olarak bulunmuştur. Ölçüm aralığı yaklaşık olarak $0{ }^{\circ} \mathrm{C}$ ile $100{ }^{\circ} \mathrm{C}$ şeklinde ayarlanmıştır. Kalorimetrik ölçüm hız $5^{\circ} \mathrm{C} /$ dakika olarak belirlenmiştir. Tarama işlemi gerçekleştirilirken sıvı kristalin olduğu alan $20 \mathrm{ml} /$ dakika akış hızına sahip azot gazı ile beslenmiştir. Ölçüme başlarken BBBA sıvı kristali $0{ }^{\circ} \mathrm{C}$ sıcaklığa soğutulmuş ve bu sıcaklıkta örnek $10 \mathrm{dk}$ bekletilmiştir. Sonrasında sabit tarama hızı ile hedef sıcaklık olan $100{ }^{\circ} \mathrm{C}$ 'ye ulaşılana kadar tarama işlemi devam etmiştir. $100^{\circ} \mathrm{C}$ 'ye ulaşıldığında ise soğutma işlemine geçilmiş ve başlangıç sıcaklığı olan $0{ }^{\circ} \mathrm{C}$ 'ye ulaşılana kadar tarama işlemi devam ettirilmiştir. İncelenen örneğin Fourier Dönüşümlü Kızılötesi (FT-IR) spektroskopisi $400 \mathrm{~cm}^{-1}$ ile $4000 \mathrm{~cm}^{-1}$ aralığında oda sıcaklığında $\left(27{ }^{\circ} \mathrm{C}\right)$ PerkinElmer spektrometre kullanılarak gerçekleştirilmiştir. POM ile elde edilen tekstürler farklı sıcaklıklarda elde edilmiştir. Benzer şekilde dielektrik ölçümleri de farklı sıcaklık değerlerinde gerçekleştirilmiştir. BBBA'nın farklı sıcaklıklara ulaştırılması Linkam LTS350 marka 1sıtıcı ile gerçekleştirilmiştir. Aynı zamanda BBBA'nın istenilen sıcaklıkta kararlı halde kalabilmesi için $\pm 0,1^{\circ} \mathrm{C}$ hassasiyete sahip Linkam TMS94 marka sıcaklık kontrolcüsü kullanılmıştır. BBBA sıvı kristali birçok smektik mezofazı sergilemektedir. Bu mezofazların tespit edilebilmesi için sıv1 kristaller genellikle güçlü manyetik alanlara maruz bırakılmaktadırlar. Bu nedenle mezofaz tekstürleri belirlenirken BBBA sıvı kristali Varian Associates V-3601 marka elektromıknatıs kullanılarak 1 T manyetik alanda tutulmuştur. POM görüntülemeleri ve dielektrik ölçümler gerçekleştirilirken ITO ile kaplanmış/kaplanmamış cam hücreler kullanılmıştır. Bu hücrelerin hazırlanma prosedürü daha önceki çalışmalarımızda ayrıntıları ile belirtilmiştir [22-24].

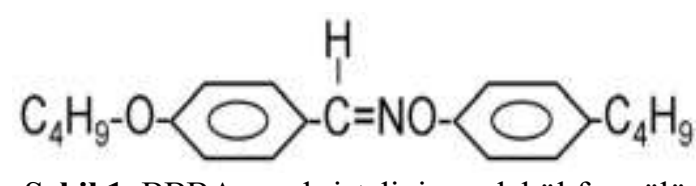

Şekil 1. BBBA sıvı kristalinin molekül formülü

\section{Bulgular ve Tartışma}

BBBA sıvı kristalinin morfolojik özelliklerinin incelenmesi için POM tekniği kullanılmıştır. POM sistemine entegre yüksek çözünürlüklü kamera ile BBBA'nın optik tekstürleri farklı sıcaklık değerlerinde elde edilmiştir. Sıvı kristalik fazların belirlenmesinde POM tekniği yaygın şekilde kullanılan bir tekniktir. Her bir sıvı kristal faz, kendine has optik tekstür sergilemektedir [7]. Siv1 kristaller POM altında, mezofaz sıcaklık bölgelerinde optiksel geçirgenliğe sahiplerdir. Optiksel geçirgenliği olmadığı sıcaklık bölgeleri izotropik sıvı faz olarak tanımlanmaktadır [25]. Şekil 2'de yöneltilmemiş cam hücreler arasında ince film halinde bulunan BBBA sıvı kristalinin optik tekstürleri bulunmaktadır. Şekil 2a'da BBBA'nın I-N faz geçişinde elde edilen optik tekstürü verilmektedir. Her iki fazın birbirinden ayrıldığı bölge kırmızı kesikli çizgilerle belirtilmiştir. Aslında, birinci dereceden faz geçişlerde geçiş bölgesi çizgilerle gösterildiği gibi keskin değildir, bir heterofaz alanı oluşmaktadır. $\mathrm{Bu}$ alanda her iki faz da kararlı halde değildir ve bu alanın genişliği hücre kalınlığı, sıvı kristal türü, demirleme enerjisi (anchoring energy) gibi farklı parametrelere bağlı olarak değişmektedir [2, 7, 26-28]. 
Şekil 2b'de ise BBBA'nın N mezofazı görülmektedir. $\mathrm{Bu}$ tekstür, Schlieren tekstürü olarak adlandırılmaktadır ve N mezofaz için karakteristiktir [25]. Bu tür tekstürlerde kıvrımlı kusur yapıları (inversiyon duvarları) ve tekil nokta kusurları (singularities) sıklıkla gözlenmektedir. Şekil 2c'de ise SmB- SmG faz geçiş tekstürü bulunmaktadır. Her iki mezofazın ayrımı mavi kesikli çizgi ile netleştirilmiştir. Bu mezofazlarda tekil ve kıvrımlı kusurlar kaybolarak tane (domain) yapılar ortaya çıkmaktadır.

a)
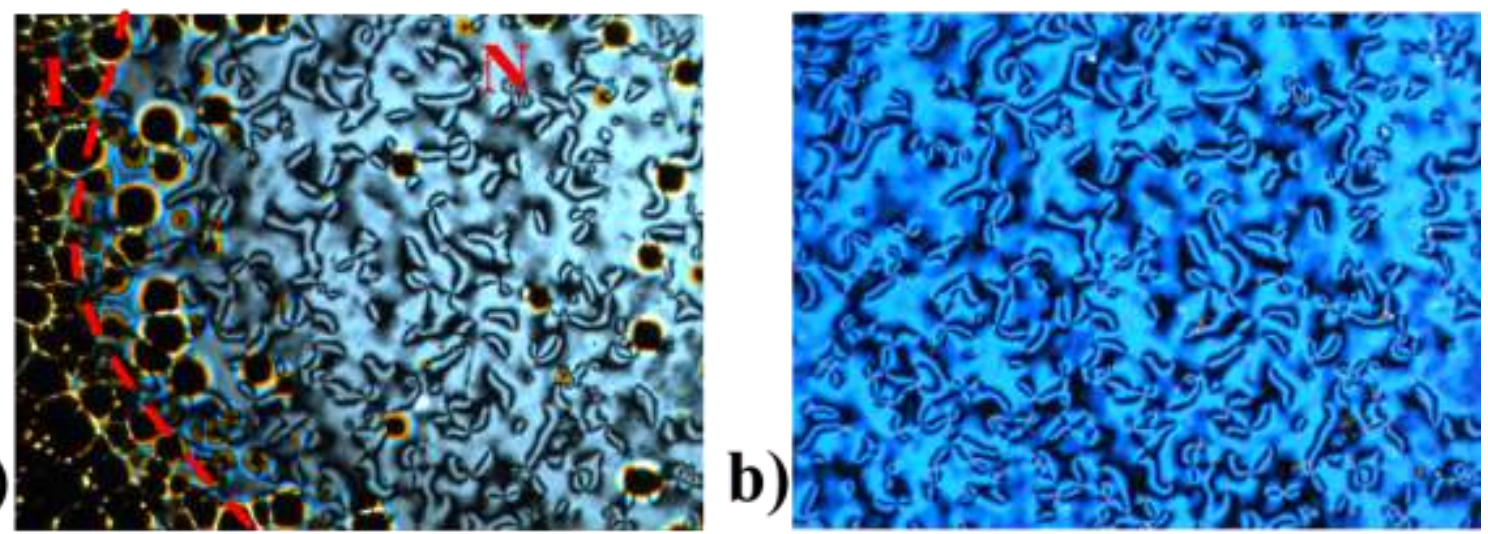

c)

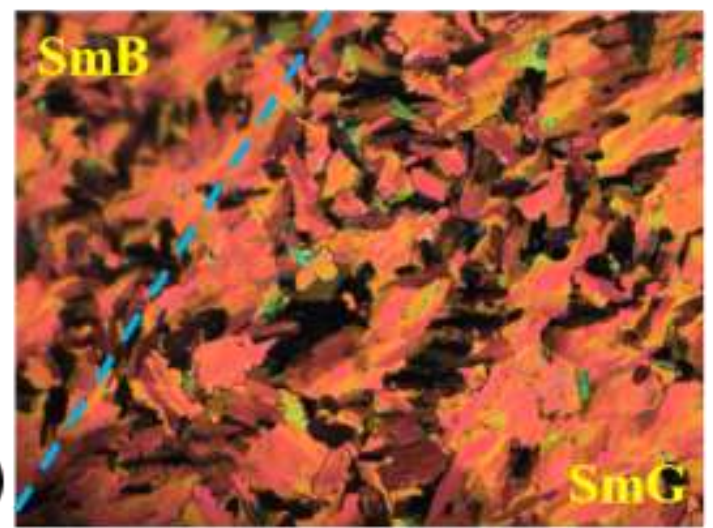

Şekil 2. BBBA'nın optik tekstürleri verilmektedir. a) I-N faz geçişi tekstürü b) N mezofaz tekstürü c) SmB-SmG faz geçiş tekstürü.

Şekil 3'te BBBA'nın belirli bir bölgesinden alınmış ve farklı sıcaklık değerlerinden tekstürleri bulunmaktadır. N mezofazda ortaya çıkan Schlieren tekstürdeki inversiyon duvarlar SmB mezofaza geçildiğinde tane sınırları haline dönüşmektedir (Şekil 3a-b). Literatürde BBBA için N mezofaz ile SmB mezofazları arasında $0,5^{\circ} \mathrm{C}$ gibi oldukça düşük faz aralığına sahip SmA mezofazının da varlığ 1 tespit edilmiştir $[16,29,30]$. Bu mezofazın oldukça dar bir sıcaklık aralığında var olmasından dolayı tespiti oldukça zordur. Bu tür dar sıcaklık aralığında var olan mezofazların belirlenmesi için çok düşük tarama hızlarında kalorimetrik ölçümler yapmak gereklidir. Şekil 3b'de BBBA'nın mozaik tekstürde SmB mezofazı görülmektedir. Optik görünümünde $\mathrm{SmB}$ 'nin $\mathrm{SmA}$ 'ya göre biraz daha homojen olmasıyla tekstürlerinde yalnızca çok ince değişiklikler üzerinden ayrımı yapılabilmektedir. SmB için fan-benzeri ve mozaik tür tekstürler tanımlanmaktadır. Ancak fan-benzeri tekstürün SmA'da gözlenen fan-benzeri tekstürden ayrımı oldukça zordur, mozaik tekstür ise SmB için karakteristiktir [25]. Mozaik tekstür, tane sınırlarının eşlik ettiği geniş, tekdüze optik görünüm alanları sergilemektedir. Tek tip optik görünüm alanları içinde, yön vektörü, taneden taneye değişen sabit bir yön boyunca yönlenmektedir. Mozaik tektürü çapraz polarizörler arasında döndürülerek, art arda tanecikler yok olma (optik geçirgenliğin olmaması) konumuna getirilebilmektedir [25, 31, 32]. Şekil 3c'de ise mozaik tekstür ile SmG mezofazı verilmektedir. SmB'ye göre tane sınırları daha düzenli haldedir. SmG için en yaygın gözlenen desen mozaik tekstürdür. Tekstürdeki her bir tanenin içinde optik eksen tekdüze ve homojen bir şekilde yönlenirken, uzun moleküler eksenlerin süreksiz yön değişimleri taneden taneye ilerleyerek farklı renkte mozaik yapıların gözlenmesine neden olmaktadır [25, 31, 32]. 

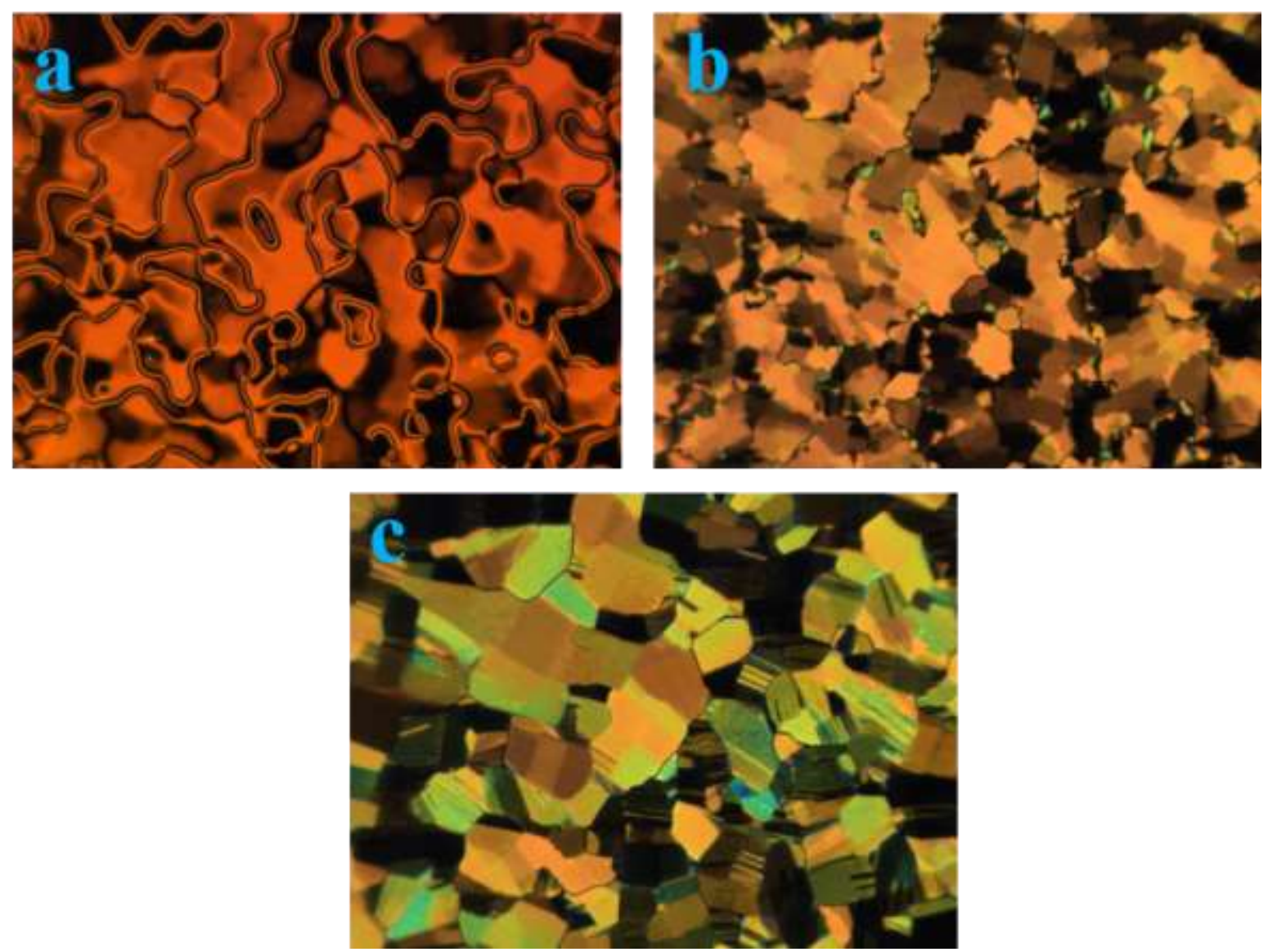

Şekil 3. BBBA'nın optik tekstürleri verilmektedir. a) N mezofaz b) SmB c) SmG tekstürü.

BBBA sıvı kristalinin dielektrik özelliklerinin sıcaklığa bağlı değişimi hem ısıtma hem de soğutma süreçlerinde ayrı ayrı incelenmiştir. Bu ölçümler $10 \mathrm{kHz}$ frekans altında gerçekleştirilmiştir. $10 \mathrm{kHz}$ 'in altındaki frekans değerlerinde safsılıklardan kaynaklanan iyonik etkiler baskın olabilmektedir. $1 \mathrm{MHz}$ ' in üzerindeki frekans değerlerinde ise sıvı kristalin içerisinde bulunduğu cam hücre kaplaması olan ITO'nun etkileri baskın olacaktır. Bu nedenlerden dolayı, dielektrik geçirgenliğin sabit olduğu frekans aralığı içerisinde bulunan $10 \mathrm{kHz}$ frekansı tercih edilmiştir. Ölçümler $25^{\circ} \mathrm{C}$ 'den başlayarak BBBA'nın izotropik faz sergilediği sıcaklık değeri olan yaklaşı $83^{\circ} \mathrm{C}$ 'ye kadar devam ettirilmiştir. Sıvı kristallerde çubuksu moleküller için nematik yön vektörü $(\boldsymbol{n})$ 'ne göre ayrı ayrı dielektrik sabitleri tanımlanmaktadır. $\boldsymbol{n}$ 'ye paralel olan bileşen $\varepsilon_{\text {paralel }}$ ve $\boldsymbol{n}$ 'ye dik olan bileşen ise $\varepsilon_{d i k}$ olarak ifade edilmektedir. Dielektrik anizotropi ise

$$
\Delta \varepsilon=\varepsilon_{\text {paralel }}-\varepsilon_{\text {dik }}
$$

eşitliği ile tanımlanmaktadır. Dielektrik anizotropi, kalıcı dipol moment ( $\mu$ )'in büyüklügü ve onun molekül uzun ekseni ile yaptığı açı ( $\beta$ )'ya bağlı olarak pozitif ya da negatif olabilmektedir [33]. Dielektrik geçirgenliğin bileşenleri moleküler düzen parametresine (S) bağlıdır. Bu durum aşağıdaki eşitlikler ile verilmektedir:

$$
\begin{aligned}
& \varepsilon_{\text {paralel }}=\bar{\varepsilon}+\frac{2}{3} \Delta \varepsilon S \\
& \varepsilon_{d i k}=\bar{\varepsilon}-\frac{1}{3} \Delta \varepsilon S
\end{aligned}
$$


Mezofaz bölgesinde ortalama dielektrik geçirgenlik olarak da tanımlanabilen dielektrik geçirgenliğin izotropik kısmı

$$
\bar{\varepsilon}=\frac{1}{3}\left(\varepsilon_{\text {paralel }}+2 \varepsilon_{\text {dik }}\right)
$$

eşitliği ile verilmektedir ve moleküler düzen parametresinden bağımsızdır.

Şekil 4 'te BBBA'nın $25^{\circ} \mathrm{C}$ 'den $83^{\circ} \mathrm{C}$ 'ye kadar isıtıldığ 1 süreçte elde edilmiş sıcaklığa bağlı dielektrik geçirgenlik grafiği bulunmaktadır. $77^{\circ} \mathrm{C}$ 'nin üzerindeki sıcaklık değerlerinde $\varepsilon_{\text {paralel }}$ ve $\varepsilon_{\text {dik }}$ değerleri üstü üste binmektedir ve tek bir sabit olarak tanımlanmaktadır $\left(\varepsilon_{\text {izotropik }}\right)$. Bu bölge izotropik sıv1 fazı olarak tanımlanmıştır. İzotropik sıv1 faz bölgesinde dielektrik sabiti $\left(\varepsilon_{\text {izotropik }}\right)$ sıcaklığın artmasıyla birlikte düzenli bir azalma sergilemektedir. Bu davranış organik bileşikler için beklenen durumdur. Mezofaz bölgesinde $\left(77^{\circ} \mathrm{C}\right.$ 'nin altındaki sıcaklık değerlerinde) N-I faz geçiş bölgesinin hemen yakınlarında denklem 4 'ten hesaplanan $\bar{\varepsilon}$ 'nın $\varepsilon_{\text {izotropik }}$ 'ten farklı olduğu tespit edilmiştir. $\mathrm{Bu}$ farkın $\mathrm{N}$ mezofazdaki moleküllerin kısa erimli antiferroelektrik düzeninden kaynaklandığı söylenebilir [33]. Denklem 4'ten hesaplanan $\bar{\varepsilon}$ 'nın N mezofaz boyunca sıcaklığın azalmasıyla artış gösterdiği görülmüştür. Bu durum, Maier-Meier teorisine göre ortalama dielektrik sabitinin artışının yönelimsel düzen parametresine bağlı olmamakla birlikte molekül yoğunluğuna bağlı olduğu şeklinde açıklanmaktadır [1]. Rao ve arkadaşlarının yaptıkları çalışmada BBBA sıvı kristalinin yoğunluğunun N mezofaz boyunca sıcaklığın azalmasıyla artış gösterdiği raporlanmıştır [8]. $77^{\circ} \mathrm{C}$ 'nin altındaki sıcaklık değerlerinde ise BBBA $\mathrm{N}$ mezofaza geçmektedir ve anizotropik malzemelerden beklendiği üzere dielektrik geçirgenlik $\varepsilon_{\text {paralel }}$ ve $\varepsilon_{d i k}$ olarak ikiye ayrılmaktadır. Yaklaş1k $57^{\circ} \mathrm{C}$ 'ye kadar $\varepsilon_{d i k}$ değeri $\varepsilon_{\text {paralel }}$ değerinden yüksek çıkmaktadır ve $57^{\circ} \mathrm{C}$ 'de her iki değer birbirine eşitlenmektedir. Bu bölgede $\Delta \varepsilon$ negatif olmaktadır. $57^{\circ} \mathrm{C}$ 'de BBBA'nın dielektrik anizotropisi $(\Delta \varepsilon)$ sifir olmaktadır. $57^{\circ} \mathrm{C}$ 'den $44^{\circ} \mathrm{C}$ 'ye kadar her ne kadar $\mathrm{N}$ mezofaz devam etse de $\varepsilon_{\text {paralel }}$ 'in $\varepsilon_{\text {dik }}$ 'ten büyük olmasından dolayı artık $\Delta \varepsilon$ pozitif olmaktadır. $\mathrm{N}$ mezofazda dielektrik geçirgenliğin işaretindeki bu değişimin gerçekleştiği sıcaklık değeri literatürde nematik 1 (N1) ile nematik 2 (N2) arasında faz geçiş sıcaklığ olarak tanımlanmaktadır $[8,17,33,34]$. $\mathrm{N}$ mezofazda ya da smektik mezofazlar içerisinde dielektrik anizotropi işaret değiştirebilmektedir. Bu işaret değişimi $\mathrm{N}$ mezofaz içerisinde bulunan smektik-benzeri kısa erimli düzene sahip cybotactic gurupların varlığından kaynaklanmaktadır [35, 36]. N mezofaz içerisinde ve smektik mezofazlardan daha yüksek sıcaklıkta ortaya çıkan bu tür smektik-benzeri düzene sahip cybotactic yapıların varlı̆̆ $\mathrm{X}$-1şını kırınım çalışmaları ile ispatlanmıştır [37]. Şekil 5'te BBBA'nın 1sıtma sürecinde $\Delta \varepsilon$ değerinin sıcaklıkla değişimi verilmektedir. Bu şekil incelendiğinde $\mathrm{N}$ mezofaz bölgesinde $\Delta \varepsilon^{\prime}$ nin negatif olduğu bölge kırmızı renkle verilen eksenin altında kalan kısım olarak açıkça görülmektedir. $44^{\circ} \mathrm{C}$ sıcaklıkta ise SmB-N faz geçişi gerçekleşmektedir. SmB mezofaz bölgesinde $\varepsilon_{\text {paralel }}$, sıcaklığın artmasıyla $\mathrm{N}$ mezofaz da görülen düzenli azalışını devam ettirmektedir. $\varepsilon_{d i k}$ ise $\mathrm{N}$ mezofaz değerlerine kıyasla faz geçiş bölgesinde keskin şekilde azalmakta ve SmB mezofazında neredeyse sabit kalmaktadır. $37^{\circ} \mathrm{C}$ 'de ise $\mathrm{SmG}-\mathrm{SmB}$ mezofaz geçişinden kaynaklanan dielektrik geçirgenlik değerlerinde belirgin değişim gözlenmektedir. SmG mezofazında sıcaklığın artmasıyla $\varepsilon_{\text {paralel }}$ düzenli bir artış gösterirken $\varepsilon_{\text {dik }}$ neredeyse sabit kalmaktadır. 


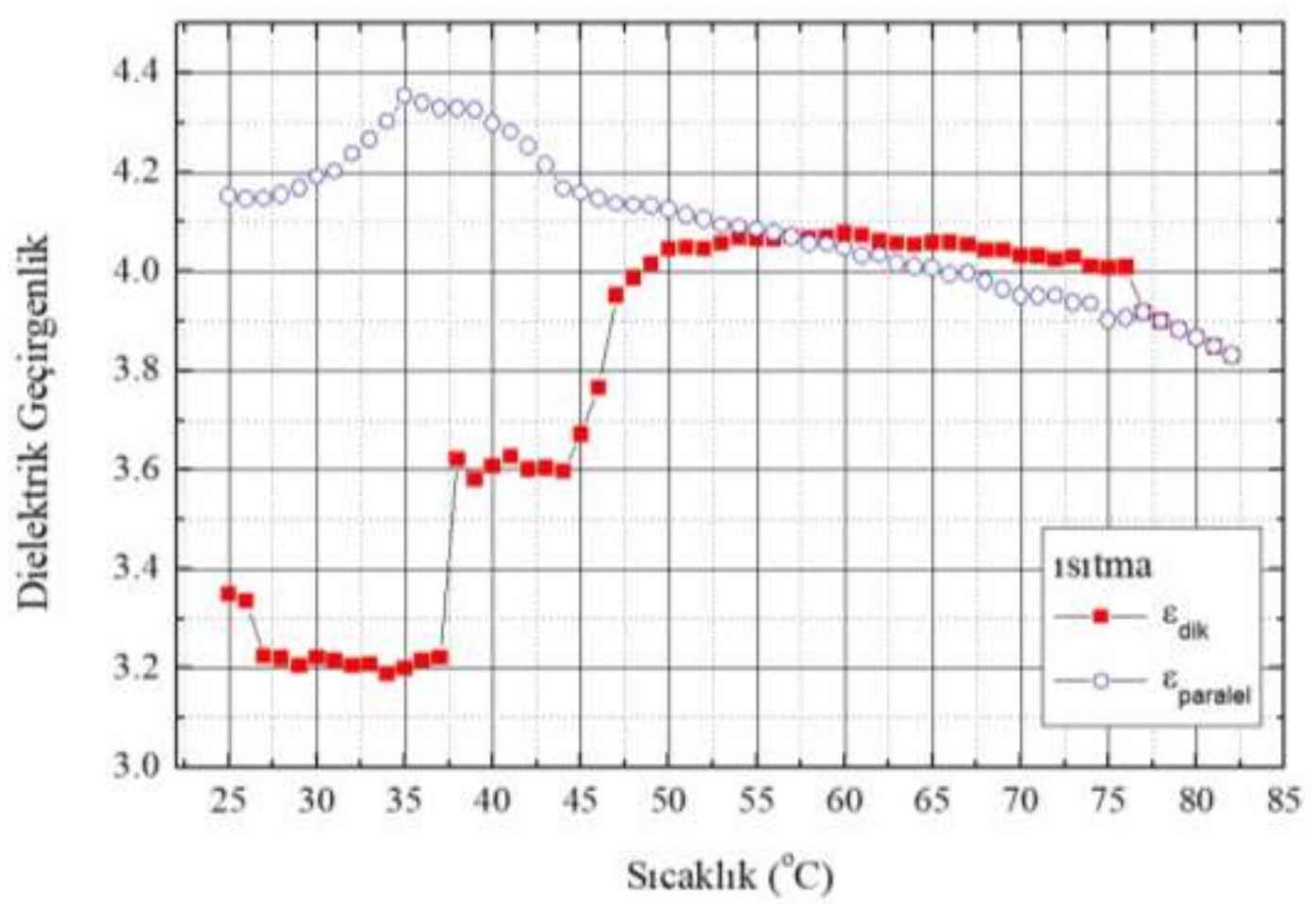

Şekil 4. BBBA’nın ısıtılması sırasında elde edilmiş sıcaklığa bağlı dielektrik geçirgenlik değerlerinin değişimi.

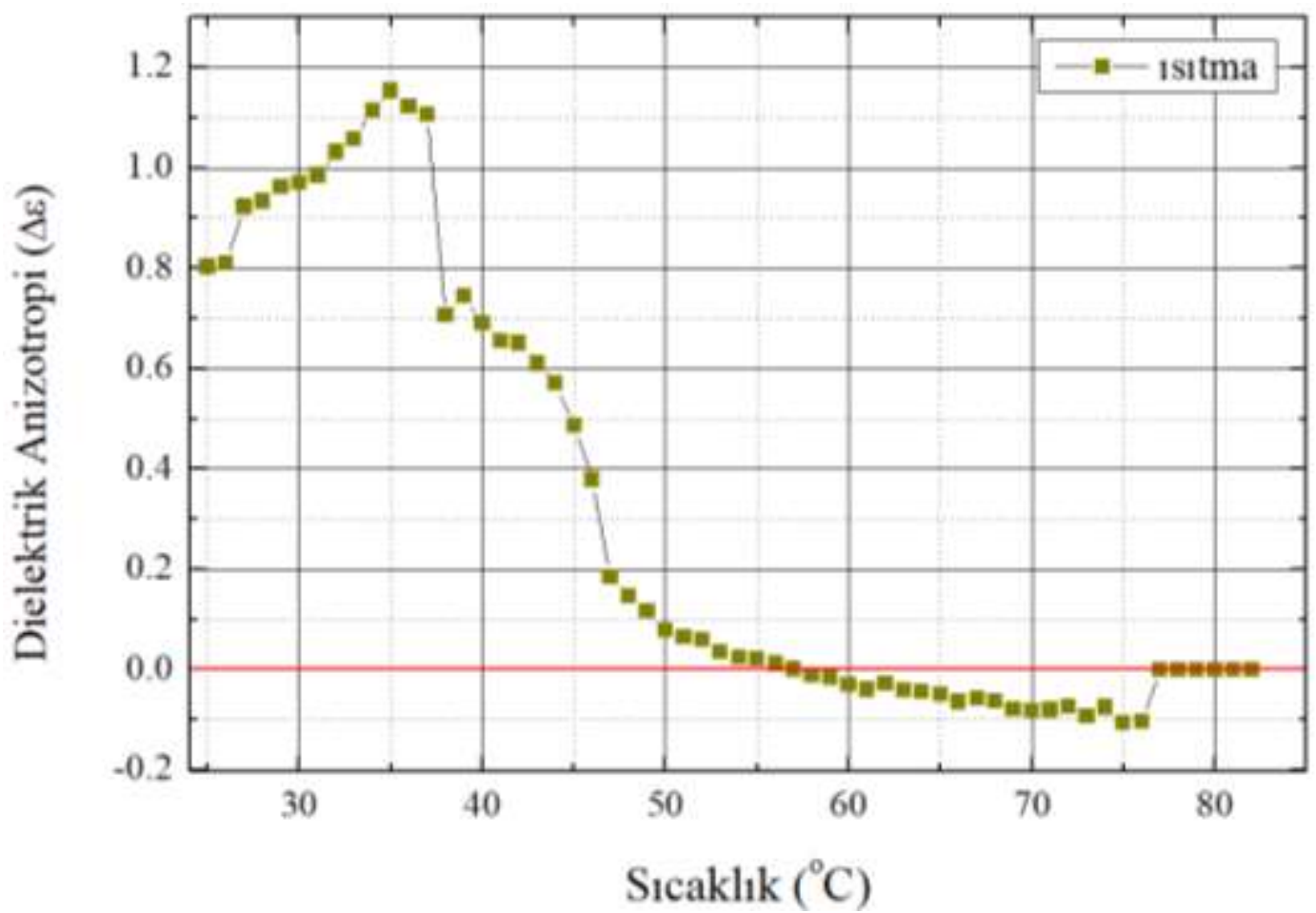

Şekil 5. BBBA’nın ısıtma sürecinde sıcaklığa bağlı dielektrik anizotropi değişimi.

Şekil 6'da BBBA sıvı kristalinin soğutma sürecinde dielektrik geçirgenlik değerlerinin sıcaklıkla değişimi verilmektedir. Dielektrik geçirgenlik değerlerinin davranışı 1sıtma grafiğindeki (Şekil 4) değişimlere oldukça benzemektedir. İzotropik faz bölgesinde $\varepsilon_{\text {paralel }}$ ve $\varepsilon_{d i k}$ üst üste binerek sıcaklığın azalmasıyla artış sergilemişlerdir ve bu bölgede $\Delta \varepsilon^{\prime}$ nin sıfır olduğu açıkça görülmektedir. I$\mathrm{N}$ faz geçişi $71^{\circ} \mathrm{C}$ 'de gerçekleşmektedir. N1-N2 faz geçişi ise $50^{\circ} \mathrm{C}$ 'de ortaya çıkmaktadır. $\mathrm{N}$ mezofaz bölgesinde $\Delta \varepsilon$ 'nin negatif ve pozitif olduğu bölgeler Şekil 7'de açık şekilde belirtilmektedir. Soğutma sırasında $\mathrm{SmB}$ ve SmG mezofazlarında dielektrik geçirgenlik değerlerinin davranışı ısıtma sırasındaki 
duruma oldukça benzemekle beraber mezofazlar arası faz geçiş sıcaklıkları farklılık göstermektedir. N$\mathrm{SmB}$ faz geçişi $40^{\circ} \mathrm{C}$ 'de, $\mathrm{SmB}-\mathrm{SmG}$ faz geçişi ise $33^{\circ} \mathrm{C}^{\prime}$ de olmaktadır. Isıtma ve soğutma süreçlerinde faz geçiş sıcaklıklarındaki bu tür farklılık termal histerezisin göstergesidir (Şekil 8). Farklı sıv1 kristallerde termal histerezisin varlığı birçok kez raporlanmıştır [19, 23, 38, 39]. Bu durum sıv1 kristallerin aşırı 1sıtılması ya da aşırı soğutulması durumunda ortaya çıkmaktadır ve birinci derece faz geçiş için karakteristik bir durumdur.

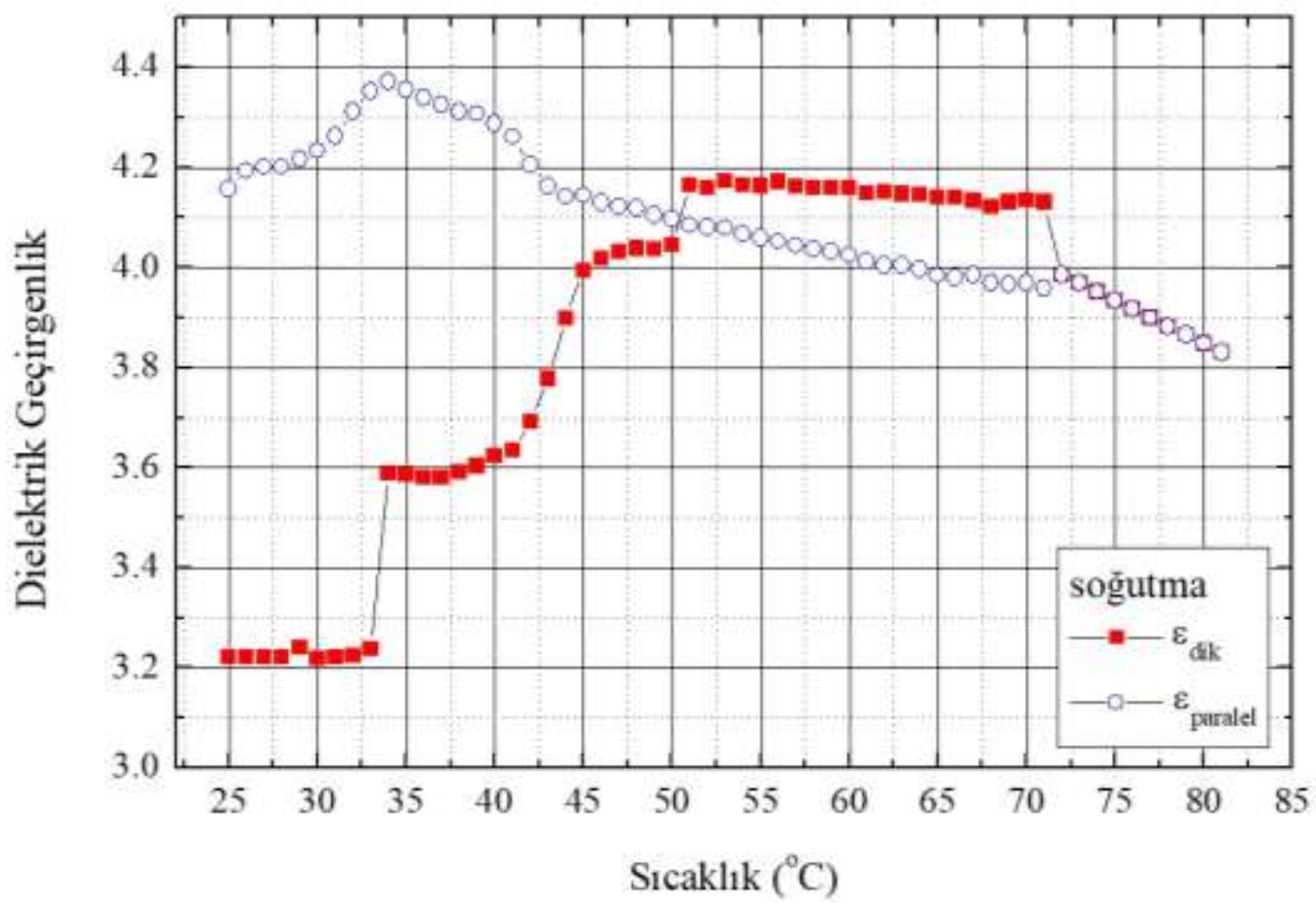

Şekil 6. BBBA’nın soğutulması sırasında elde edilmiş sıcaklığa bağlı dielektrik geçirgenlik değerlerinin değişimi.

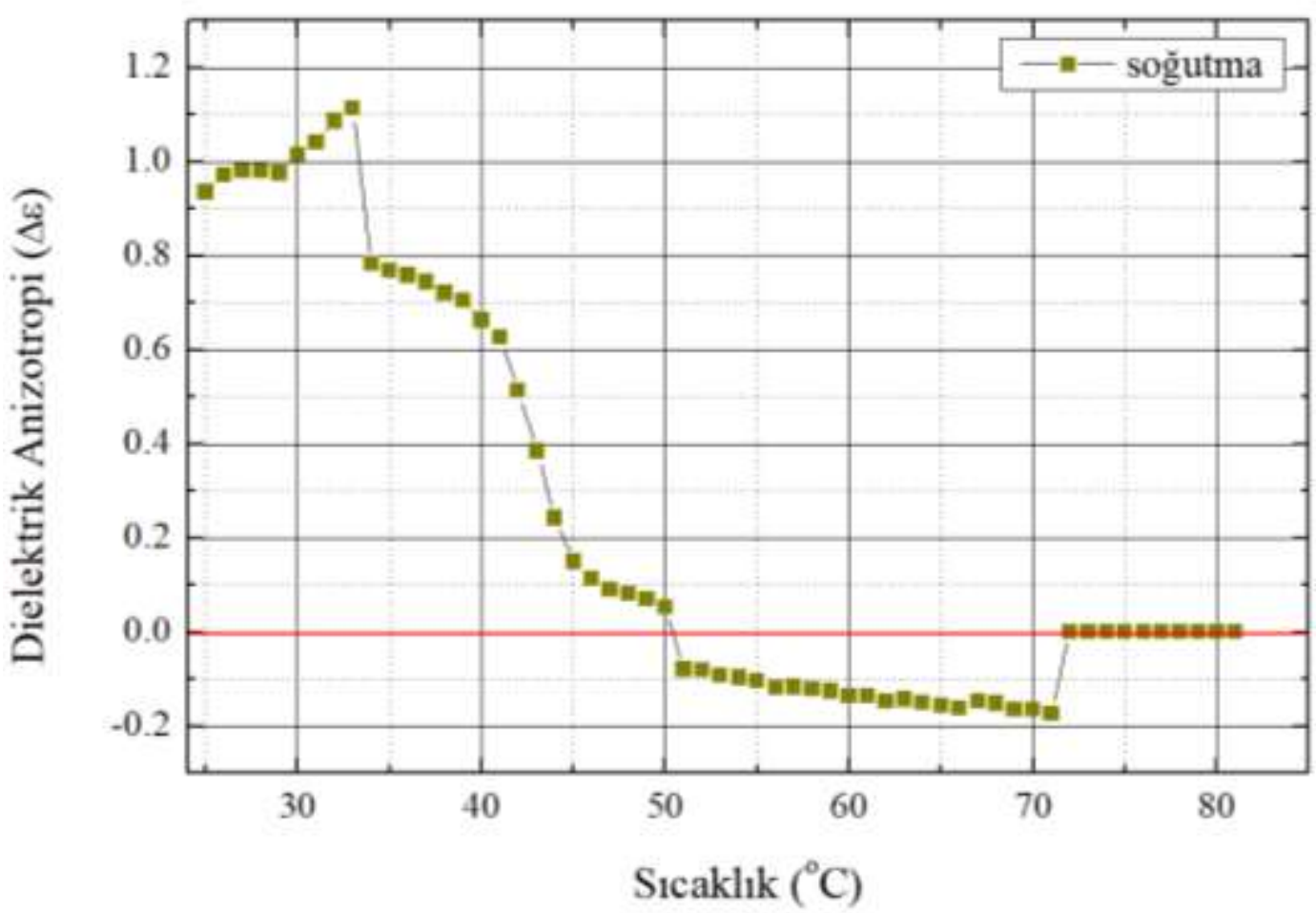

Şekil 7. BBBA’nın soğutma sürecinde sıcaklığa bağlı dielektrik anizotropi değişimi. 


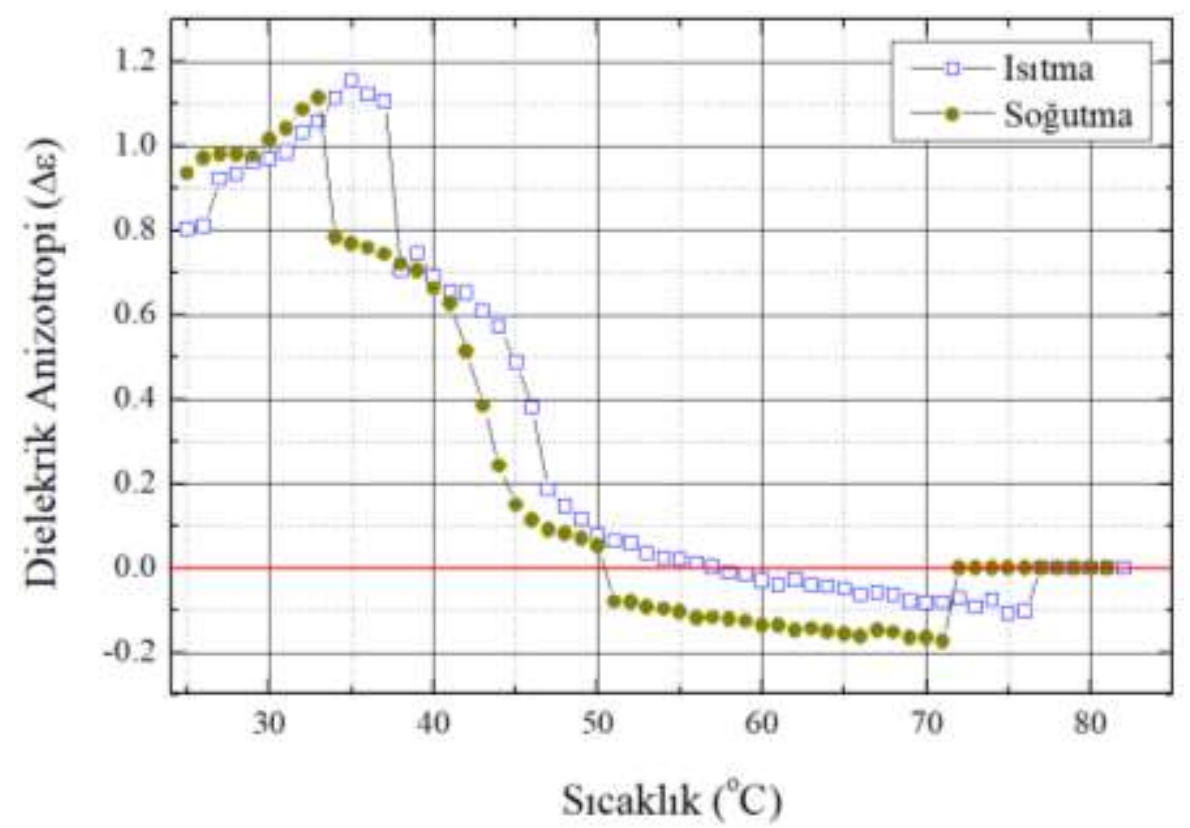

Şekil 8. BBBA'nın ısıtma ve soğutma sürecinde sıcaklığa bağlı dielektrik anizotropi değişimi ve termal histerezisin gösterimi.

Çalıșmamızda BBBA’nın kızıl ötesi spektroskopik ölçümleri gerçekleștirilmiștir. Fourier Dönüşümlü Kızılötesi (FT-IR), kimyasal süreçleri ve yapıları araştırmada yaygın olarak kullanılan bir teknik ve önemli bir araçtır. Ayrıca FTIR, kristallerdeki ve sıvı kristal bileşiklerdeki konformasyonel değişiklikleri ve polimorfizmi araştırmak için bilinen bir yöntemdir [40, 41]. Ayrıca, sıvı kristal faz geçişlerini incelemek için de yaygın olarak kullanılmaktadır. Kızı̈ötesi piklerin şekli, maksimum soğurma konumu ve soğurma yoğunluğu gibi bazı özellikleri belirli bir fazdaki moleküler etkileşimlere bağlıdır ve böylece mezofazlar hakkında bilgi edinilmesini sağlamaktadır [42]. Kızılötesi spektroskopinin parmak izi bölgesi, yapısal değişiklikler konusunda bilgiler vermektedir. Sıvı kristallerin fenil halkaları ve bağlantı grupları (azo, ester, imin) veya hidroksil gurubu ve H-bağları gibi fonksiyonel grupları hakkında karakteristik bilgiler sağlamaktadır [40, 42, 43]. Şekil 9' da BBBA sıv1 kristalinin oda sıcaklığında gerçekleştirilen FT-IR spektroskopisine ait geçirgenlik grafiği verilmektedir. Grafik üzerinde bazı temel geçirgenlik piklerinin kodları kırmızı renkte belirtilmiştir.

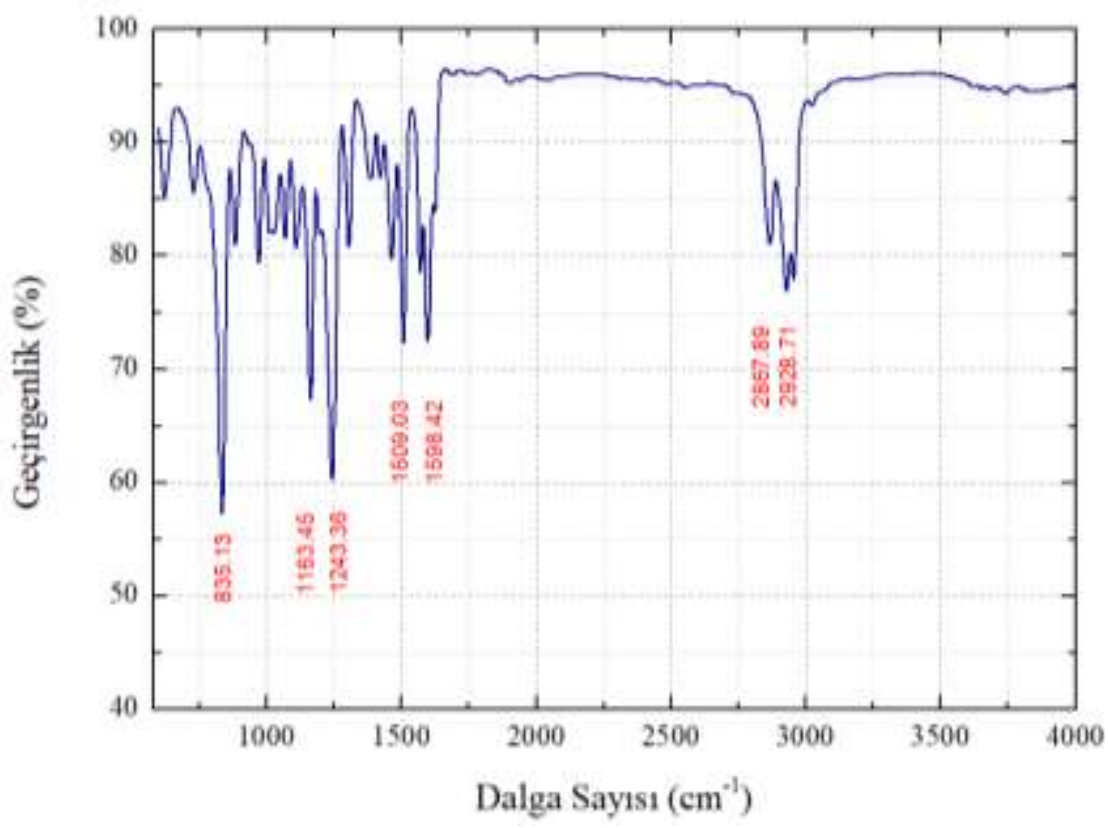

Şekil 9. BBBA sıvı kristalinin FTIR Spektroskopisi 
Tablo 1. BBBA sıvı kristalinin FTIR Spektroskopisinden elde edilen titreşim modları

\begin{tabular}{|c|c|}
\hline Dalga Sayısı $\left(\mathrm{cm}^{-1}\right)$ & Titreşim Modu \\
\hline 2955,79 & alkil zincirinin $\mathrm{CH}_{3}$ asimetrik gerilme titreşimi \\
\hline 2928,71 & alkil zincirinin $\mathrm{CH}_{2}$ asimetrik gerilme titreşimi \\
\hline 2867,89 & alkil zincirinin $\mathrm{CH}_{3}$ simetrik gerilme titreşimi \\
\hline 1598,42 & fenil halkasındaki $C=C$ gerilme titreșimi \\
\hline 1570,31 & fenil halkasındaki $C=C$ gerilme titreşimi \\
\hline 1509,03 & fenil halkasındaki $C=C$ gerilme titreşimi \\
\hline 1464,60 & alkil zincirinin $\mathrm{CH}_{2}$ makaslama titreşimi \\
\hline 1421,64 & alkil zincirinin $\mathrm{CH}_{2}$ makaslama titreșimi \\
\hline 1386,92 & fenil halkasındaki $C=C$ gerilme titreşimi \\
\hline 1305,53 & $\mathrm{CH}_{2}$ dalgalanma titreşimi \\
\hline 1243.36 & $C-O-C$ antisimetrik gerilme titreşimi \\
\hline 1163.45 & fenil halkasındaki $C-H$ gerilme titreşimi \\
\hline 1110.08 & $\mathrm{C}-\mathrm{C}$ hidrokarbon zincirlerinin gerilmesi ve $\mathrm{CH}_{2}$ bükümü \\
\hline 1012.82 & alkil-O-C asimetrik gerilme titreşimi \\
\hline 970.94 & $\mathrm{CH}_{2}$ gerilme titreşimi \\
\hline 884.54 & $\mathrm{CH}_{2}$ salınım titreșimi ve fenil halkasındaki $\mathrm{C}$ - $\mathrm{H}$ düzlen dıșı bozunum \\
\hline 835.13 & $\mathrm{CH}_{2}$ salınım titreşimi ve $\mathrm{C}-\mathrm{CH}_{3}$ gerilmesi \\
\hline 729.45 & $\mathrm{CH}_{2}$ salınım titreşimi \\
\hline
\end{tabular}

Tablo 1'de BBBA'ya ait tüm titreşim modları verilmektedir. BBBA molekülü siyano gurubu ile birbirine bağlı iki fenil halkasının uçlarında alkil ve alkoksi guruplarının bağlı olduğu bir yapıdır. Tablo 1 incelendiğinde bu moleküle ait spektroskopinin alkil zincirinde $\mathrm{CH}_{3}$ ve $\mathrm{CH}_{2}$ asimetrik titreşim ve fenil halkasında $C=C$ gerilme titreşim modları görülmektedir. $2960 \mathrm{~cm}^{-1}$ ile $2800 \mathrm{~cm}^{-1}$ dalga sayısı aralığında ortaya çıkan pikler aromatik ya da alifatik $C-H$ gerilme titreşimleri olarak değerlendirilebilmektedir. Alkil zinciriyle ilişkili $\mathrm{CH}_{2}$ asimetrik gerilme titreşimi $2928 \mathrm{~cm}^{-1}$ 'de sivrilir, bu da çok sayıda kıvrımı olan düzensiz bir molekül kuyruğuna işaret etmektedir [44, 45]. Özellikle, $1480 \mathrm{~cm}^{-1}-1430 \mathrm{~cm}^{-1}, 1370 \mathrm{~cm}^{-1}-1300 \mathrm{~cm}^{-1}$ ve $750 \mathrm{~cm}^{-1}-710 \mathrm{~cm}^{-1}$ aras1 spektral bölgelerin pikleri alkil zincir yapısına duyarlı olduğu bilinmektedir [46].

Sıvı kristalik faz maddenin belirgin ve bağımsız bir hali olmasına rağmen birçok farklı sıvı kristalik faz türü vardır. Farklı sıvı kristalik fazlar ve diğer mezofazlar tanımlanmalı ve sonrasında fazın yapısını oluşturan moleküler düzenlerine göre sınıflandırılmalıdır. Bu bağlamda, çalışmamızda BBBA sıvı kristalinin hem 1sıtma hem de soğutma sırasında kalorimetrik ölçümleri DSC tekniği kullanılarak gerçekleştirilmiştir. DSC ölçümleri tek başına sıvı kristalik mezofazların tanımlanmasında kullanılamamaktadır. Bununla birlikte, entalpi değiş̧imindeki durum bir mezofaz içinde moleküler düzenin derecesi ile ilgili bazı bilgileri vermesi sebebiyle bu teknik genellikle optiksel mikroskobi ile birlikte sıvı kristalik mezofazların tanımlanmasında sıklıkla kullanılmaktadır. Mezofazlar arası entalpi değişimi esas alınarak kristal-mezofaz, mezofaz-mezofaz ve mezofaz-izotropik sıvı faz geçişler hakkında kıymetli bilgiler edinilmektedir [2, 7, 47, 48]. Şekil 10'da BBBA sıvı kristalinin sıcaklığa bağlı 1S1 akış grafiği verilmektedir. Grafikte kırmızı renkli eğri katı kristal fazdan izotropik faza devam eden 1sıtma esnasındaki tarama eğrisidir. BBBA 1sıtılırken ilk olarak $42,1^{\circ} \mathrm{C}$ 'de görece küçük faz geçiş piki gözlenmektedir. Bu pik SmG-SmB faz geçişine karşılık gelmektedir. $48,0^{\circ} \mathrm{C}$ 'de ise oldukça büyük bir başka pik ortaya çıkmaktadır. Bu pik ise SmB-N faz geçişine karşılık gelmektedir ve güçlü birinci derece faz geçişi olarak tanımlanmaktadır. Bu geçişte BBBA katı fazdan sıvı faza geçmiştir. Literatürde SmB ile N mezofazları arasında çok dar bir sıcaklık aralığında ortaya çıkan SmA mezofazı da raporlanmıştır [16, 17, 29, 30, 33, 34]. SmA mezofazının tespit edildiği çalışmalarda söz konusu mezofazın tespit edilmesi için $0,01^{\circ} \mathrm{C}$ /dakika gibi oldukça düşük tarama hızlarında çalışmalar gerçekleştirilmiştir. Çalışmamızda tarama hızı $5^{\circ} \mathrm{C}$ /dakika olarak belirlenmiştir ve termo-grafik üzerinde SmA mezofazına karşılık gelecek herhangi bir pik gözlenmemektedir. Şekil $10^{\prime}$ da $77,2^{\circ} \mathrm{C}^{\prime}$ de N-I faz geçişine ait pik görünmektedir. Sıvı kristallerde mezofaz-izotropik faz geçiş pikleri belirgin şekilde daha küçüktür ve zayıf birinci derece geçişin olduğunu belirtmektedir [2]. Isıtma işlemi sonrasında BBBA sıvı kristali bu kez soğutulurken termal tarama işlemi devam ettirilmiştir. Bu taramayı gösteren eğri Şekil 7'de siyah 
renk ile belirtilmiştir. I fazdan $\mathrm{N}$ mezofaza geçiş $75,9^{\circ} \mathrm{C}$ 'de olmaktadır. Isıtma ve soğutma durumlarında $\mathrm{N} \leftrightarrow \mathrm{I}$ faz geçişleri arasında $1,3^{\circ} \mathrm{C}$ 'lik bir fark vardır. Bu durum faz geçişler için termal histerezis olarak tanımlanmaktadır. Termal histerezisin varlığı dielektrik ölçümlerde de tespit edilmiştir. $\mathrm{N}-\mathrm{SmB}$ faz geçiş piki ise $45,8^{\circ} \mathrm{C}$ 'de ortaya çıkmıştır. $\mathrm{Bu}$ geçişte ise 1 sıtma ve soğutma arasında $2,2^{\circ} \mathrm{C}$ 'lik bir fark vardır. SmB-SmG faz geçişine karşılık gelen pik $38,8^{\circ} \mathrm{C}$ 'de görülmektedir. Isıtma ve soğutma süreçlerinde bu faz geçiş için $3,3^{\circ} \mathrm{C}^{\prime}$ lik sıcaklık farkı bulunmaktadır. DSC ve dielektrik ölçümleri sonucunda elde edilen faz geçiş sıcaklıkları arasında ve aynı zamanda her iki ölçüm için termal histerezis değerlerinde farklar olduğu tespit edilmiştir. Dielektrik ölçümlerinde BBBA, $30 \mu \mathrm{m}$ kalınlığa sahip planar ve homeotropik yöneltilmiş (işlenmiş) düzgün cam hücrelere doldurularak incelenmiştir [22-24]. DSC ölçümlerde ise sıvı kristal yığın halde ölçülmüştür. Cam hücrelerde, hücrenin oldukça ince olmasından dolayı incelenen sıvı kristal üzerinde yüksek demirleme etkisi (anchoring effect) oluşmaktadır. Bu etki özellikle mezofaz geçişlerinde etkili olmaktadır. Yığın halde ölçülen sıvı kristallerde bu etki oldukça azdır. Bu nedenle incelenen sıvı kristalin ölçüm durumu faz geçiş sıcaklıklarını ve mezofaz aralıklarını öteleyebildiği gibi faz geçişlerde ortaya çıkan termal histerezisin büyüklügünü de etkilemektedir $[49,50]$.

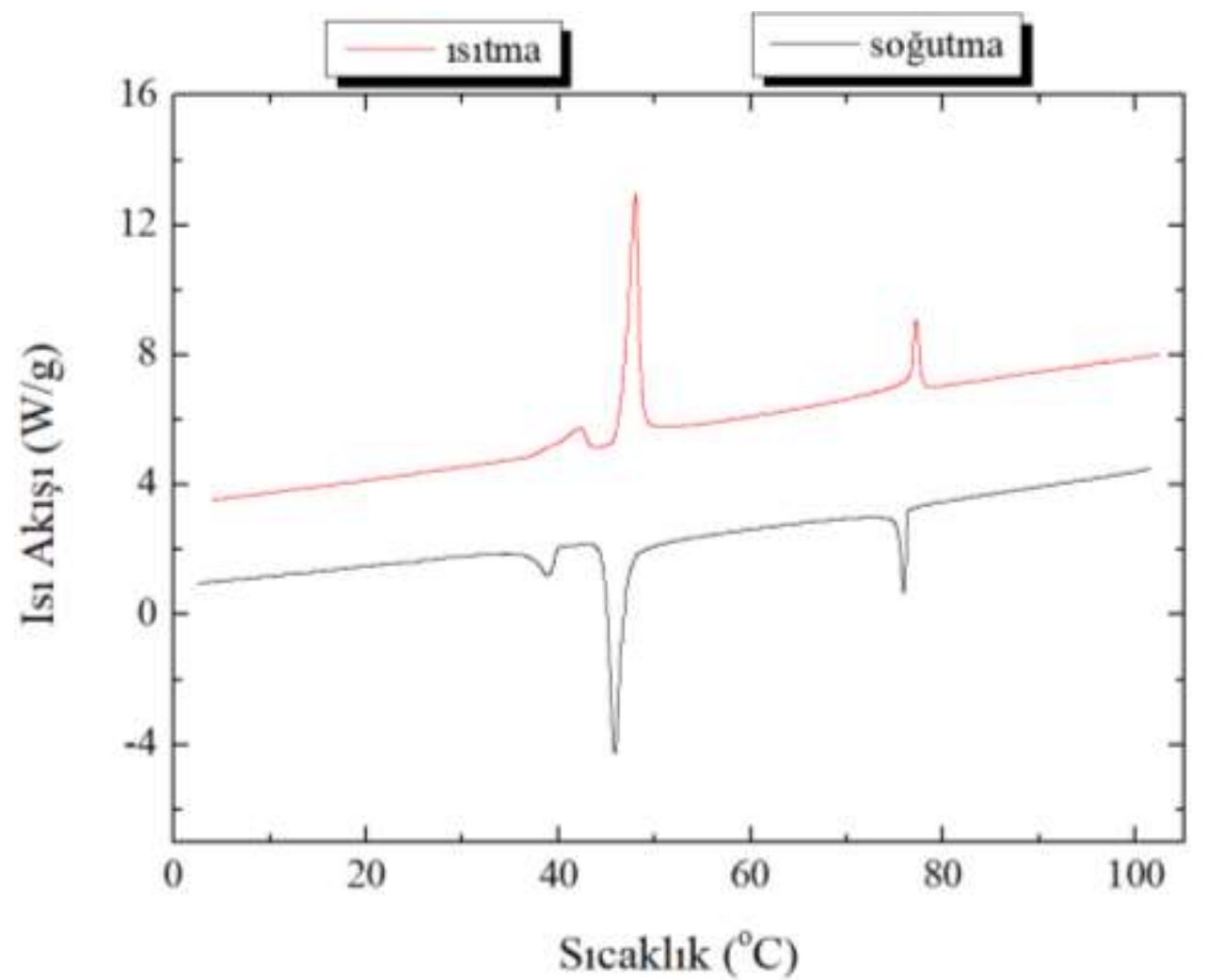

Şekil 10. BBBA sıvı kristalinin ısıtma ve soğutma durumlarında elde edilen DSC eğrileri.

\section{Sonuç ve Tartışma}

Bu çalışmada, BBBA sıvı kristalinin morfolojik, dielektrik, kızılötesi spektroskopik ve kalorimetrik özellikleri üzerine araştırma yapılmıştır. Morfolojik özelliklerin incelenmesi için optik tekstürleri alınarak örneğin mezofazlarda ve faz geçişlerinde ortaya çıkan desen ve kusur yapıları belirlenmiştir. N mezofaz bölgesinde Schlieren türü desen ve bu desende inversiyon duvarlar ve tekil noktaların ortaya çıtığ1 tespit edilmiştir. SmB ve SmG mezofazlarda taneli bir yapıyı simgeleyen karakteristik mozaik tekstürün varlı̆g 1 belirlenmiştir. Yapılan dielektrik ölçümler sonucunda $\mathrm{N}$ mezofazda iki farklı faz oluştuğu belirlenmiştir. N1 ve N2 olarak adlandırılan iki fazın geçişinde dielektrik anizotropinin sıfır değerini aldığı açıkça görülmektedir. BBBA; N1 fazında negatif, N2 fazında ve diğer smektik mezofazlarda pozitif dielektrik anizotropiye sahiptir. Dielektrik ölçümlerine göre BBBA'nın 1sıtma ve 
soğutma durumlarında farklı faz geçiş sıcaklıklarına sahip olduğu tespit edilmiştir. Bu durum termal histerezisin varlığını ortaya koymaktadır ve bu birinci derece faz geçişler için beklenen bir durumdur. Termal histerezisin varlığı DSC ölçümlerinde de ortaya çıkmıştır. Dielektrik ve DSC ölçümlerinde elde edilen faz geçiş sıcaklıkları ve termal histerezis kıyaslandığında farklı sıcaklıklarda gerçekleştikleri görülmüştür. Bu farkın sebebi, cam hücrelerde sıvı kristalin yüksek demirleme etkisinde kalmasından dolayıdır. Çalışmada ayrıca, BBBA sıvı kristalinin kızılötesi spektroskopisi çalışılmıştır. Yapılan ölçümlerde molekülün geçirgenlik piklerinin karşılığı olan kimyasal bağlar ve guruplar tanımlanmıştır. Tanımlanan bu yapılar, BBBA'nın sergilediği mezofazlar arası geçiş dinamiklerinin anlaşılmasında ve molekülün kristalik paketlenme durumları üzerine yapılacak çalışmalar için oldukça faydalı olacaktır.

\section{Teşekkür}

Yazarlar, teknik desteklerinden dolayı Muğla Sttk1 Koçman Üniversitesi Araştırma Laboratuvarları Merkezi'ne teşekkür etmektelerdir.

\section{Yazarların Katkısı}

A.E.M. deneysel ölçümleri ve bunların analizini yapmıştır, aynı zamanda makalenin yazımını gerçekleştirmiştir. N.A. deneysel ölçümleri ve bunların analizini yapmıştır.

\section{Çıkar Çatışması Beyanı}

Yazarlar arasında herhangi bir çıkar çatışması bulunmamaktadır.

\section{Araştırma ve Yayın Etiği Beyanı}

Yapılan çalışmada araştırma ve yayın etiğine uyulmuştur.

\section{Kaynaklar}

[1] Demus D., Goodby J., Gray G.W., Spiess H.-W., Vill V. 1998. Handbook of Liquid Crystals.Wiley-VCH, Weinheim, 1-2591.

[2] Blinov L.M. 2011. Structure and Properties of Liquid Crystals. Springer, Dordrecht, Heidelberg, London, New York, 1-458.

[3] Bendahou A., Khouba Z., Benabdallah T., Maschke U. 2018. Mesophase study of pure and doped cyanobiphenyl liquid crystals with salen-type systems. Liq Cryst., 45: 1312-1323.

[4] Archambeau S., Bock H., Seguy I. 2007. Organic solar cells with an ultra thin organized hole transport layer. J Mater Sci Mater Electron., 18 (9): 919-923.

[5] Matharu A.S., Jeeva S., Ramanujam P.S. 2007. Liquid crystals for holographic optical data storage. Chem Soc Rev., 36 (12): 1868-1878.

[6] Vertogen G., de Jeu W.H. 1988. Thermotropic Liquid Crystals, Fundamentals. Springer, Dordrecht, Heidelberg, London, New York, 1-325.

[7] Collings P.J., Hird M. 2017. Introduction to liquid crystals: Chemistry and physics. Taylor and Francis, London, 1-305.

[8] Rao J.V., Rao N.V.S., Pisipati V.G.K.M., Murty C.R.K. 1980. Density Studies in N-(p-nButoxybenzylidene)-p-n-Butylaniline. Berichte der Bunsengesellschaft für Phys Chemie, 84: 1157-1160.

[9] Deschamps J., Trusler J.P.M., Jackson G. 2008. Vapor pressure and density of thermotropic liquid crystals: MBBA, 5CB, and novel fluorinated mesogens. J Phys Chem B., 112 (13): 3918-3926.

[10] Diaconu I., Melniciuc-Puică N., Dorohoi D., Aflori M. 2007. Birefringence dispersion of N-(4methoxybenzylidene)-4-butylaniline (MBBA) determined from channeled spectra. Spectrochim Acta - Part A Mol Biomol Spectrosc., 68 (3): 536-541.

[11] Sudhadevi Antharjanam P.K., Prasad E. 2010. Nematic to smectic texture transformation in MBBA by in situ synthesis of silver nanoparticles. New J Chem., 34 (3): 420-430. 
[12] Xu Z.D., He Y.N., Guo M.C., Wang X.G. 2007. Alternating current electric-field-induced tunable microstructures and electrohydrodynamic convection properties observed in azo-dye-doped MBBA liquid crystal cells. J Appl Phys., 102 (2): 67-80.

[13] De Luca G., Emsley J.W., Lesage A., Merlet D. 2012. The structures and conformations of mesogenic molecules in the pre-transitional region of the isotropic phase: 5OCB and MBBA and their mixtures. Liq Cryst., 39 (2): 211-219.

[14] Bertocchi M.J., Ratchford D.C., Casalini R., Wynne, James H., Lundin, J.G. 2018. Electrospun Polymer Fibers Containing a Liquid Crystal Core: Insights into Semiflexible Confinement. J Phys Chem C, 122: 16964-16971.

[15] Celebre B.G., De Luca G., Ferrarini A. 1997. Short-and long-range contributions to the ordering of rigid planar solutes dissolved in a 55wt\% ZLI1132+ EBBA nematic mixture. Mol Phys., 92 (6): 1039-1050.

[16] Mitra S., Mukhopadhyay R., Venu K. 2000. Molecular motions in liquid crystal BBBA (4O.4): QENS study. Chem Phys., 261: 149-156.

[17] Lebovka N.I., Lisetski L.N., Goncharuk A.I. 2013. Phase transitions in smectogenic liquid crystal 4-butoxybenzylidene- 4'-butylaniline (BBBA) doped by multiwalled carbon nanotubes. Phase Transitions, 86: 463-476.

[18] Kleman M., Lavrentovich O.D. 2004. Soft Matter Physics: An Introduction. Springer New York, New York, 1-63.

[19] de Gennes P.G., Prost J., Pelcovits R. 1995. The Physics of Liquid Crystal. Phys Today, 48 (5): 70-71.

[20] Singh S., Dunmur P.D.A. 2002. Nematic Liquid Crystals: Elastostatics and Nematodynamics. In: Liquid Crystals, Edited by Khoo I.C., Wiley-Interscience, New Jersey, 174-220.

[21] Khoo I.C., Wu S.T. 1993. Optics and Nonlinear Optics of Liquid Crystals. World Scientific, Singapur, 1-440.

[22] Avci N., Borshch V., Sarkar D.D. 2013. Viscoelasticity, dielectric anisotropy, and birefringence in the nematic phase of three four-ring bent-core liquid crystals with an L-shaped molecular frame. Soft Matter., 9: 1066-1075.

[23] Mamuk A.E., Nesrullajev A., Mukherjee P.K. 2017. Refractive and birefringent properties of 4alkyl-4'-oxycyanobiphenyls at direct and reverse phase transitions. Mol Cryst Liq Cryst., 648 (1): 168-181.

[24] Özden P., Mamuk A.E., Avc1 N. 2019. Investigation of the viscoelastic properties of 4-propoxybiphenyl-4-carbonitrile. Liq Cryst., 46 (15): 2190-2200.

[25] Dierking I. 2003. Textures of Liquid Crystals. Wiley-VCH, Weinheim, 1-233.

[26] Oswald P., Pieranski P. 2005. Smectic and Columnar Liquid Crystals. Taylor \& Francis, Boca Raton, 1-711.

[27] Doi M. 2013. Soft Matter Physics. Oxford University Press, Oxford, 1-257.

[28] Kleman M., Lavrentovich O.D. 2004. Soft Matter Physics: An Introduction. Springer, New York, $1-63$.

[29] Heng M., De-Heng S., Jun H., Yu-Feng P. 2009. Simulation study on terahertz vibrational absorption in liquid crystal compounds. Chinese Phys B., 18: 1085-1088.

[30] Smith G.W., Gardlund Z.G. 1973. Liquid crystalline phases in a doubly homologous series of benzylideneanilines-textures and scanning calorimetry. J Chem Phys., 59: 3214-3228.

[31] Robertson J.H. 1980. Textures of liquid crystals by D. Demus and L. Richter. Acta Crystallogr Sect A., 36 (6): 1096-1096.

[32] Demus D., Diele S., Grande S., Sackmann H. 1983. Polymorphism In Thermotropic Liquid Crystals. In: Advances in Liquid Crystals edited by Brown, G.H., Vol: 6, Academic Press, New York, San Francisco, London, 1-107.

[33] Rao J.V., Murty C.R.K. 1985. Dielectric Studies In N-(P-N-Butoxybenzylidene) P-NButylandine. Phase Transitions, 5: 139-144.

[34] Rao J.V., Murty C.R.K. 1985. Ultrasonic Investigations of N- (P-N-Pentyloxybenzylidene) P-NButylaniline. Phase Transitions, 5: 145-150.

[35] de Jeu W.H., Lathouwers T.W., Bordewijk P. 1974. Dielectric Properties of di-n-Heptyl Azoxybenzene in the Nematic and in the Smectic-A Phases. Phys Rev Lett., 32: 40-43. 
[36] de Jeu W.H., Goossens W.J.A., Bordewijk P. 1974. Influence of smectic order on the static dielectric permittivity of liquid crystals. J Chem Phys., 61: 1985-1989.

[37] Vries A.D. 1970. Evidence for the Existence of More Than One Type of Nematic Phase. Mol Cryst Liq Cryst., 10 (1-2): 31-35.

[38] Mamuk A.E., Nesrullajev A. 2016. Refractive and birefringent properties and order parameter of nematic liquid crystal at the direct and reverse nematic $\leftrightarrow$ isotropic liquid phase transition. $\mathrm{J}$ Optoelectron Adv Mater., 18 (11-12): 928-937.

[39] Hosaka S., Tozaki K.I., Hayashi H., Inaba H. 2003. Effect of magnetic field on the phase transitions of EBBA by means of a high-resolution and super-sensitive DSC. Phys B Condens Matter., 337: 138-146.

[40] Avadanei M., Perju E., Cozan V., Bruma M. 2014. Phase transitions of a monotropic azomethine liquid crystal investigated by ATR-FTIR spectroscopy. Phase Transitions, 87: 243-254.

[41] Martínez-Felipe A., Imrie C.T., Ribes-Greus A. 2013. Study of structure formation in side-chain liquid crystal copolymers by variable temperature fourier transform infrared spectroscopy. Ind Eng Chem Res., 52: 8714-8721.

[42] Osiecka N., Galewski Z., Juszyńska-Gałązka E., Massalska-Arodź M. 2016. Studies of reorganization of the molecules during smectic $\mathrm{A}-$ smectic $\mathrm{C}$ phase transition using infrared spectroscopy and generalized two-dimensional correlation analysis. J Mol Liq., 224: 677-683.

[43] Singh S., Singh H., Srivastava A. 2016. Study of phase transitions in a bent-core liquid crystal probed by infrared spectroscopy. Vib Spectrosc., 86: 24-34.

[44] Enomoto S., Ozaki Y., Kuramoto N. 1993. Comparative Study of Langmuir-Blodgett Films of Three Kinds of Dyes Containing a 2-[[4'-(Mono- or dialkylamino)phenyl- or naphthyl]azo]-Nmethylbenzothiazolium Chromophore by Infrared, Visible Absorption, and Resonance Raman Spectroscopies. Langmuir., 9 (11): 3219-3224.

[45] Fernsler J.G., Glaser M.A., Shao R. 2017. Aggregation-driven, re-entrant isotropic phase in a smectic liquid crystal material. Liq Cryst., 44 (5): 769-783.

[46] Papadopoulos P., Grigoriadis C., Haase N. 2011. Dynamics of Structure Formation in a Discotic Liquid Crystal by Infrared Spectroscopy and Related Techniques. J Phys Chem B., 115 (50): 14919-14927.

[47] Smith G.W. 1990. Study of Formation, Phase Behavior, and Microdroplet Size of a Polyurethanebased Polymer-dispersed Liquid Crystal. Mol Cryst Liq Cryst Inc Nonlinear Opt., 180: 201-222.

[48] Smith G.W., Vaz N.A. 1988. The relationship between formation kinetics and microdroplet size of epoxy-based polymer-dispersed liquid crystals. Liq Cryst., 3: 543-571.

[49] Alexe-Ionescu A.L., Barberi R., Bonvent J.J., Giocondo M. 1996. Nematic surface transitions induced by anchoring competition. Phys Rev E - Stat Physics, Plasmas, Fluids, Relat Interdiscip Top, 54: 529-535.

[50] Soltani T., Marcerou J.P., Othman T. 2013. Thermal hysteresis at the phase transition in liquid crystalline materials. Liq Cryst., 40: 165-171. 